\title{
Uncertain Supply Chain Management
}

homepage: www.GrowingScience.com/uscm

\section{The effect of digital marketing on customer relationship management in the education sector: Peruvian case}

\author{
Sofía Oré-Calixto ${ }^{\mathrm{a}}$ and Wagner Vicente-Ramos ${ }^{\mathrm{b}^{*}}$
}

${ }^{a}$ Universidad Continental, Peru

\section{H R O N I C L E}

\section{Article history:}

Received April 2, 2021

Received in revised format May

15,2021

Accepted June 92021

Available online

June 102021

Keywords:

Digital marketing

Operational management

Analytical management

CRM

Customer

\begin{abstract}
A B S T R A C T
The objective of the research was to determine the impact of Digital Marketing on customer relationship management (CRM) in an educational institution in central Peru. The study was carried out from the quantitative approach, with a non-experimental correlational transactional research design. A questionnaire was applied to 228 parents between the ages of 30 and 50 who belong to an educational institution in the city of Concepción in Peru. Using the structural equations model, it was found that Content Marketing has a significant influence on the operational management of customer relationships $(p<0.05)$, as well as on the analytical management of customer relationships $(\mathrm{p}<0.05)$. Regarding the Marketing of social networks, it was identified that it has a significant influence on the operational management of customer relationships ( $p<0.05$ ), as well as on the analytical management of customer relationships $(p<0$, $05)$, because the media used by educational institutions are attractive to parents. It is concluded that Digital Marketing has a great impact on customer relationship management (CRM) in the educational sector of a city in central Peru.
\end{abstract}

\section{Introduction}

Today's dynamic and uncertain environment has contributed to the changing nature of markets. For companies to keep up, they will need to embark on new wave marketing to take advantage of the opportunities provided by changes in the environment, such as the digital revolution (Kotler et al., 2019). For this reason, digital marketing has become an indispensable tool for companies, since its effective use generates customer loyalty and retention, through interaction with them.

Digital marketing has evolved, progressively and very quickly, with profound changes, both in the techniques and in the tools used. Guerreiro and Loureiro (2020) analyze how the different users of social networks interact and disseminate communication related to the causes of the digital age (expansion of Information and Communication Technologies) and how people search for advertising campaigns marketing related to your tastes and preferences according to your culture. Also, Viana (2020) indicates that services are changing as companies require more analytical and technological skills. These new demands overlap with the integration of social media data into customer relationship management (CRM) tools to improve customer information.

According to Dastane (2020) in developed countries of America and some other European countries, CRM is established as an approach to learn and influence customer behavior by writing meaningful communications to get more customers and retain existing customers. In fact, CRM ensures customer loyalty and profitability of the organization.

In Peru, Digital Marketing is not as widely used by most companies since in 2017 it was evidenced that only $34.5 \%$ invest in

* Corresponding author

E-mail address: wvicente@ continental.edu.pe (W. Vicente-Ramos)

(c) 2021 Growing Science Ltd. All rights reserved.

doi: $10.5267 /$ j.uscm.2021.6.007 
digital advertising, this investment has been in constant growth since 2013; however, he is not a prominent figure in Management (2018). According to Drew et al. (2017), they say that social media and digital marketing materials influence the social, economic and ecological complexities that surround the quinoa industries in Peru and Bolivia. Likewise, Fong (2019) mentions that the industry in general has adapted to the new needs of the Peruvian market by offering digital solutions that provide timely information, comfort and modernity when acquiring a new product or service. On the other hand, more than $50 \%$ of SMEs (micro and small companies) in Peru run the risk of disappearing due to lack of customers for not taking advantage of recently developed digital tools, this prevents SMEs from attracting new customers, reducing their sales at minimal levels. Therefore, the use of digital tools and predictive analytics will define a new sales channel that allows the identification of customer tastes and the creation of new marketing and sales strategies. (Aquino-Arrieta et al., 2020). At present, the educational institutions of the Peruvian state face a decrease in demand, generated by competition, since in the educational sector, year after year, private educational institutions with better quality of service have been created; implementation of technology in their means of communication and dissemination of information, these institutions present a good management of digital Marketing, which allows them to have a direct relationship with their clients. This state educational institution, located in a province in central Peru and with more than 55 years of operation, showed a growth of 670 students in secondary level students until 2015 and decreased to 560 students by 2019 , which means a decrease of $16.4 \%$ in the student body population. There are factors such as poor customer service, the misuse of digital media or the preference for competition that caused this notable decrease in students, so it was proposed to determine if the implemented Digital Marketing strategies influence the management of the relationship with the client (CRM).

\section{Literature review}

\subsection{Digital Marketing}

It is a marketing component that capitalizes on the use of digital technologies, such as the Internet or social media applications (for example, Facebook, YouTube, Instagram, and Twitter), to deliver commercial messages directed to specific audiences on their smartphones, tablets, and computers. It is characterized by the interactivity and personalization of messages, as well as the ability to disseminate information about products using specific methods and volumes that exceed the capacity of traditional media (Amson, Remedios, Pinto and Kent, 2021). According to Del Toro (2020), digital marketing combines digital technologies to contribute and facilitate marketing activities; its use, in general, makes the acquisition of goods and services profitable, since it continuously increases the acquisition of customers. With this, digital technology and the development of the planned approach acquire strategic recognition and allow companies to improve their knowledge of the customer, as well as their tastes, preferences, and products (presentation, quality, quantity) in order to satisfy their needs. Its application leads to facilitating processes for national and international trade, where various techniques are used to devise business models and strategies aimed at detecting opportunities in global markets, so it is necessary for companies to develop forms of communication and integrate a marketing plan, to segment their markets and learn about the social networks used in each country. Professionals in the field of digital marketing consider that if a product or service is not found on the Internet, it simply does not exist (Bricio Samaniego et al., 2018).

\subsubsection{Content marketing}

Content marketing is defined as a strategy that is based on creating, publishing, and sharing content, by digital means, these must be useful and of high quality (Kotler et al., 2017). It is the way to capture the attention of the consumer through quality content, but from the point of view of optimization. The proper dissemination and promotion of it, allows us to achieve not only respect as an industry leader, but also with the objective of increasing qualified traffic to our assets (Velázque-Cornejo \& Hernández-Gracia, 2011).

\subsubsection{Social media market}

According to Cortado and Chalmeta (2016), marketing in social media is a form of social interaction, that is, spaces of connectivity and coexistence. They are defined by the dynamic exchanges between the users that integrate them. Social networks are open and horizontal systems that bring together groups of people with the same needs and problems. Therefore, they are constituted as a form of social organization that allows a group of individuals to enhance their resources and solve problems. Likewise, Kumar et al. (2016) affirms that it is a relatively inexpensive communication approach, which opens up new opportunities for brands to extract value from current and potential consumers, providing new forms of interaction between brands and said consumers. A well - established fan base can significantly strengthen consumer-brand relationships.

\subsection{Customer relationship management (CRM)}

According to Alqershi, Mokhtar and Abas (2020) is a business approach that understands and impacts customer behavior through effective interactions with them to improve customer attraction, retention, loyalty, and ultimately profitability, CRM is important to vision and top management's CRM strategy for its employees. This interaction between the organization and its employees is also important to ensure that the CRM process can be successful in achieving objectives and improving the performance of the organization. Successful CRM implementation can increase customer satisfaction and retention rate and also increase employee satisfaction and subsequently improve business performance. 


\subsubsection{Operational CRM}

For Jayanthi and Vimala (2019), the operational CRM is a combination of human factors, maintenance factors, process factors, technological factors and strategic management practices that generates a better understanding of the client for the development, segmentation and adequate targeting of the product. , campaign management and maintenance of profitable, long-term and mutually beneficial relationships with clients.

\subsubsection{Analytical CRM}

It refers to the analysis phase of the data collected during the relationship with the customer, helps to describe their behavior, understand their habits, develop appropriate marketing plans for organizations to identify sales transactions and build a longterm loyalty relationship term. (Wassouf et al., 2020)

\section{Research model and hypotheses}

For the Digital Marketing construct, the following indicators and questions were considered:

a) Content Marketing (MC): Do you consider the design of the educational institution's website attractive to stay? (MC1), do you consider that browsing the educational institution's website is a pleasant experience? (MC2), for you, is the information published on the website reliable? (MC3), Based on your website visit, did you find the appropriate information about the educational institution? (MC4), would you recommend the use of the website to the people around you? (MC6).

b) Marketing in social networks (MR): Do you use social networks through your mobile to access the virtual platforms of the educational institution? (MR1), do you consider that the content published on the educational institution's social network Facebook is attractive? (MC2), would you recommend the social network Facebook to the people around you? (MC3), how often do you visit the educational institution's Facebook social network? (MC4), Are you satisfied with the educational institution's Facebook social network? (MC5), do you share, react and comment on the publications made by the institution on the social network Facebook? (MC6).

The CRM construct was made up of the following indicators and their respective questions:

a) Operational CRM (CO): Do you consider receiving agile and personalized attention from the educational institution? (CO1), do you consider that the institution responds quickly to your complaints or suggestions when you approach the educational center? $(\mathrm{CO} 2)$, do you receive advertising in your email from the institution? (CO3), do you receive advertising from the Institution on your social networks? (CO4).

b) Analytical CRM (CA): Do you consider that the service provided (education) by the institution is adequate? (CA1), would you recommend the institution for the service (education) it provides? (CA2), have you had the experience or have you known that the Institution makes discounts according to the number of children at the time of enrollment? (CA4).

From which the following conceptual model and hypothesis are established:

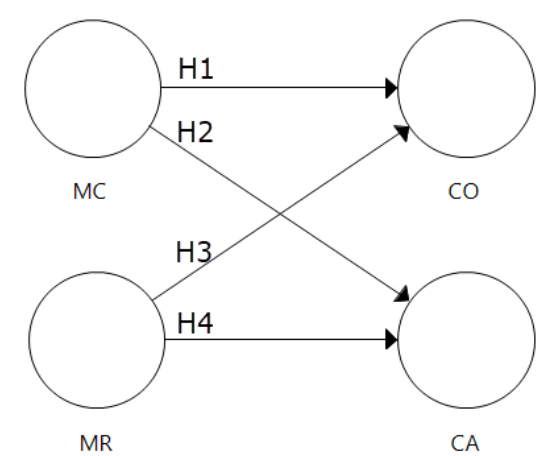

Fig. 1. Conceptual model and hypotheses

$\mathbf{H}_{1}$ : Content Marketing (MC) positively influences the operational management of customer relationships (CO).

$\mathbf{H}_{2}$ : Content Marketing (CM) positively influences analytical customer relationship management (CA).

$\mathbf{H}_{3}$ : Marketing based on social networks (MR) positively influences the operational management of customer relationships $(\mathrm{CO})$.

H4: Marketing based on social networks (MR) positively influences analytical customer relationship management (CA).

\section{Method}

The present study applied the deductive inferential scientific method, for which the type and level of applied and explanatory research were used respectively, since it is intended to measure the causal link that exists between the study variables. 
Likewise, the research design used is the non-experimental cross-sectional design.

\subsection{Population and simple}

The population is made up of parents at the secondary level of the educational institution, who add up to a total of 560 individuals made up of men (43.4\%) and women (56.6\%), with an age range between 30 - 50 years, who were the object of study. The sample size (228 parents from the secondary level of a public secondary education institution) was obtained with a margin of error of $5 \%$, a " $p$ " factor of 0.5 and a "q" of 0.5 , the confidence level of the $95 \%$.

\subsection{Data collection instrument}

A questionnaire was designed and applied to parents at the secondary level of the educational institution. The structure of the instrument presents 11 items for the Digital Marketing variable (five from content marketing and six from social media marketing) and 7 items for the customer relationship management (CRM) variable (four from operational CRM and three from Analytical CRM). For the validation of the instrument, the validation sheet was used by expert criteria, likewise the reliability was determined by means of Cronbach's Alpha coefficient, for the content marketing variable (0.913), social media marketing variable (0.915), CRM variable operational (0.858)) and CRM analytical variable (0.792).

\section{Results}

\subsection{Assessment of the Measurement Model}

Table 1 shows the measurement analysis of the model, based on the reliability and validity of the measurement scales. Regarding reliability, the internal consistency of the scales is evidenced through the Cronbach Alpha value (between 0.785 to 0.880 ) and the composite reliability (between 0.860 to 0.916 ). With respect to convergent validity, all factor loadings are above 0.700 . Likewise, all the scales have percentages of average variance extracted (AVE) greater than $50 \%$. The discriminant validity of the construct was tested by the Fornell Larcker criteria, which verifies the independence of each of the scales, considering that the square root of the AVE is greater than the correlations with the rest of the scales. In all cases, the assumption was met.

Table 1

Results of the model measurement analysis

\begin{tabular}{ccccc}
\hline Variables & $\begin{array}{c}\text { Cronbach } \\
\text { alpha }\end{array}$ & $\begin{array}{c}\text { Composite } \\
\text { reliability }\end{array}$ & Factor loads (range) & $\begin{array}{c}\text { Average variance } \\
\text { extracted (AVE) }\end{array}$ \\
\hline MC & 0.913 & 0.935 & $0.779-0.895$ & 0.743 \\
MR & 0.915 & 0.934 & $0.738-0.915$ & 0.705 \\
CO & 0.858 & 0.903 & $0.790-0.894$ & 0.862 \\
CA & 0.792 & 0.880 & $0.738-0.927$ & 0.700 \\
\hline
\end{tabular}

As shown in Fig. 2, in all cases, R-Square greater than 0.500 was obtained, which is very significant, showing that the model significantly explains the variance of the conceptual constructs of the dependent variable.

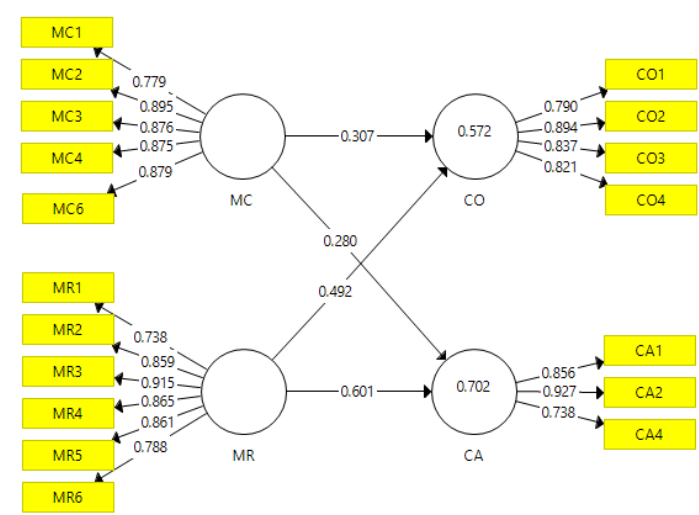

Fig. 2. Results for the hypothesized model with structural equations

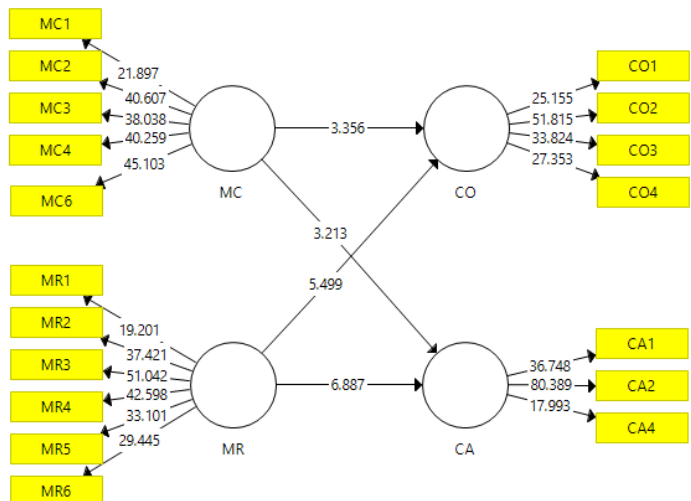

Fig. 3. Digital Marketing Modeling and Customer Relationship Management

\section{Assessment of the Structural Model}

After verifying the validity and reliability of the measurement model, the relationships of the constructs were tested. The hypotheses were tested by examining the road coefficients and their significance levels. Bootstrapping was performed with 6000 subsamples to verify the statistical significance of each of the road coefficients (Curo et al., 2020). Fig. 3 shows the estimated trajectory of the PLS analysis. Table 2 shows the contracting of results, where the 4 hypotheses are accepted (p $<0.05)$. 
Table 2

Results of the model structure analysis

\begin{tabular}{|c|c|c|c|c|c|}
\hline Hypotheses & Mean sample & Standard deviation & Beta & p value & Decision \\
\hline $\mathrm{MC} \rightarrow \mathrm{CO}$ & 0.302 & 0.091 & 3.356 & 0.001 & Accept H1 \\
\hline $\mathrm{MC} \rightarrow \mathrm{CA}$ & 0.277 & 0.087 & 3.213 & 0.001 & Accept H2 \\
\hline $\mathrm{MR} \rightarrow \mathrm{CO}$ & 0.497 & 0.09 & 5.499 & 0.000 & Accept H3 \\
\hline $\mathrm{MR} \rightarrow \mathrm{CA}$ & 0.604 & 0.087 & 6.887 & 0.000 & Accept H4 \\
\hline
\end{tabular}

\section{Discussion and conclusion}

Based on the results obtained, this document provides a description of the impact of Digital Marketing on customer relationship management (CRM) in the education sector in a city in central Peru.

Regarding the influence of Content Marketing in the operational management of customer relationships:

In the study, content marketing was found to have a positive impact on the operational management of customer relationships. These results are in line with those of Cuevas-Molano, Sánchez-Cid and Matosas-López (2019), they affirm that the brand content strategy positively influences new avenues of research in organizational communication in digital environments through a bibliometric analysis. Faced with this new paradigm, it is essential to analyze the effects that brand content has, both on users and on organizations, which must adapt their content strategy on social networks to activate some type of action on their audiences. It is concluded that Content Marketing does significantly impact the correct management of relationships with customers at the Operational level, since the digital media used by the educational Institution are attractive to parents, improving the effective interaction and communication that is necessary for the customer to feel satisfied with the service provided.

\section{Regarding the influence of Content Marketing in the analytical management of customer relationships:}

Research results show that content marketing has a great impact on customer relationship management. Likewise, Kumar et al. (2020), points out that the development of communication technologies is positively influencing digital marketing since it achieves its greater scope, providing benefits to all business sectors to offer the best product and service to its customers. Likewise, the Chatterjee et al. (2021) mentions that integrated artificial intelligence has influenced customer relationship management (CRM) systems, revolutionizing the means of organizations by adjusting them to the artificial intelligence customer service system (AICS) and the broader digitization environment relevant information so that managers of different companies can implement these findings to redesign and increase their services. It is concluded that Content Marketing does significantly impact the correct management of customer relationships at an Analytical level, since the use of digital media is an important factor for the customer to rate the evaluation of the service offered by the educational institution when making use of technology., the client finds greater possibilities of being attended to with any doubt or suggestion that he presents.

\section{Regarding the influence of Marketing based on social networks in the operational management of customer} relationships:

Marketing based on social networks has a great impact on the operational management of customer relationships. Botero, Arias, Hernández and Cano (2021), affirms that information technology factors and the phenomenon of social networks have influenced to give rise to new asynchronous digital tools, increasing the dialogue between companies and consumers. Identifying these factors makes it easier to design strategies to retain current customers and reach potential customers. It is concluded that Marketing in Social Networks is significantly related to the correct management of relationships with customers at the Operational level, since it allows the customer to consider receiving agile and personalized attention from the educational Institution and with it feel satisfaction for the service offered, making it rule out the possibility of a transfer of educational establishment.

Regarding the influence of Marketing based on social networks in the analytical management of customer relationships:

Marketing based on social media significantly influences the analytical management of customer relationships. These results are in line with the study by Itani et al. (2020), the results reveal that the use of social networks and CRM technology positively influence information exchanges between buyers and sellers; however, each technology takes a different route to enable the exchange of information between the buyer and the seller. The results suggest that managers should promote the use of both technological applications in their sales force. It is concluded that Marketing in Social Networks does have a significant impact on the correct management of customer relationships at an Analytical level, since the management of social networks makes parents know relevant information about the activities carried out in the institution, giving a clear vision. of the education their minor children receive. This also means that parents can perceive and be sure that the school provides a quality service. 


\section{References}

Alqershi, N., Mokhtar, S. S. M., \& Abas, Z. B. (2020). Innovative CRM and Performance of SMEs: The Moderating Role of Relational Capital. Journal of Open Innovation: Technology, Market, and Complexity, 6(4), 155.

Amson, A., Remedios, L., Pinto, A., \& Kent, M. P. (2021). Exploring the extent of digital food and beverage related content associated with a family-friendly event: a case study. BMC Public Health, 21(1), 1-9.

Aquino-Arrieta, K., Fernandez-Mejia, F., Cespedes-Blanco, C., Raymundo-Ibañez, C., \& Alvarez, J. M. (2020, February). Business Architecture Model Adapted to Predictive Analysis for Customer's Increasing of SMEs of Furnitures Industry through Digital Tools. In 2020 9th International Conference on Industrial Technology and Management (ICITM) (pp. 176-180). IEEE.

Botero, D. A., Arias, A. V., Hernández, J. B., \& Cano, L. D. (2021). Factors that promote social media marketing in retail companies. Contaduría y administración, 66(1), 9.

Bricio Samaniego, K., Calle Mejia, J., \& Zambrano Paladines, M. (2018). Digital marketing as a tool for labor performance in the ecuadorian environment: case study of graduates from the University of Guayaquil. Revista universidad y sociedad, 10(4), 103-109.

Coca Cola Journey. (2017). Coca Cola Perú. Retrieved from Bodegas peruanas: retos y fortalezas de los negocios del barrio: https:/www.cocacoladeperu.com.pe/historias/comunidad-bodegas-peruanas-retos-y-fortalezas-de-los-negocios-delbarrio

Cuevas-Molano, E., Sánchez-Cid, M., \& Matosas-López, L. (2019). Bibliometric analysis within studies of brand content strategy in social media. Comunicación y sociedad, 16.

Cortado, F. J., \& Chalmeta, R. (2016). Use of social networks as a CSR communication tool. Cogent Business \& Management, 3(1), 1187783.

Curo, Y. G., De la Cruz Amaro, J., \& Vicente-Ramos, W. (2020). Impact of e-commerce on the performance of agroexports in the central region of Peru. Acta Logistica, 7(4), 301-307.

Chatterjee, S., Chaudhuri, R., Vrontis, D., Thrassou, A., \& Ghosh, S. K. (2021). Adoption of artificial intelligence-integrated CRM systems in agile organizations in India. Technological Forecasting and Social Change, 168, 120783.

Dastane, O. (2020). Impact of Digital Marketing on Online Purchase Intention: Mediation Effect of Customer Relationship Management. Journal of Asian Business Strategy, 10(1), 142-158.

Drew, J., Sachs, A. D., Sueiro, C., \& Stepp, J. R. (2017). Ancient grains and new markets: the selling of quinoa as story and substance. In Corporate Social Responsibility and Corporate Governance. Emerald Publishing Limited.

Guerreiro, J., \& Loureiro, S. (2020). Cause-Related Marketing in the Digital Era: How Enterprises Can Deal with International Campaigns in Individualist Versus Collectivist Countries. Voluntas: International Journal of Voluntary and Nonprofit Organizations, 31(6), 1330-1342.

Del Toro, G. (2020). El impacto del marketing digital en empresas fabricantes de embutidos de los Altos de Jalisco. RICEA Revista Iberoamericana de Contaduría, Economía y Administración, 9(18), 1-19.

Itani, O. S., Krush, M. T., Agnihotri, R., \& Trainor, K. J. (2020). Social media and customer relationship management technologies: Influencing buyer-seller information exchanges. Industrial Marketing Management, 90, 264-275.

Jayanthi, L. \& Vimala, V. (2019). Influence of process and technology factors in successful implementation of CRM in private sector banks. International Journal of Advanced Science and Technology, 28(20), 95-101.

Kotler, P., Kartajaya, H., \& Hooi, D. H. (2019). Asian competitors: Marketing for competitiveness in the age of digital consumers. World Scientific.

Kumar Sharma, N., Chen, W. K., \& Lai, K. K. (2020). Challenges and Prospects for Digital Marketers while Dealing with SMEs: An Interview. In 2020 The 4th International Conference on Software and e-Business (pp. 25-31).

Kumar, A., Bezawada, R., Rishika, R., Janakiraman, R., \& Kannan, P. K. (2016). From social to sale: The effects of firmgenerated content in social media on customer behavior. Journal of Marketing, 80(1), 7-25.

Velázque-Cornejo, B. I., \& Hernández-Gracia, J. F. (2019). Marketing de contenidos. Boletín Cientifico de la Escuela Superior Atotonilco de Tula, 6(11), 51-53.

Viana, J., van der Zandt, M., Reinhold, O., \& Alt, R. (2020, June). Outsourcing of Social CRM Services in German SMEs. In International Conference on Business Information Systems (pp. 215-228). Springer, Cham.

Wassouf, W. N., Alkhatib, R., Salloum, K., \& Balloul, S. (2020). Predictive analytics using big data for increased customer loyalty: Syriatel Telecom Company case study. Journal of Big Data, 7, 1-24.

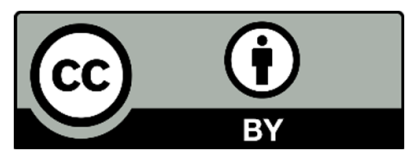

(C) 2021 by the authors; licensee Growing Science, Canada. This is an open access article distributed under the terms and conditions of the Creative Commons Attribution (CCBY) license (http://creativecommons.org/licenses/by/4.0/). 